\title{
DIVERSITY AND DISTRIBUTION OF LICHENS OF AMBULUWAWA MOUNTAIN
}

\author{
A Gunasekara and SC Wijeratne \\ Department of Botany, University of Sri Jayewardenepura, Nugegoda
}

Ambuluwawa Mountain in Gampola District reaches to a height of 1065 meters and vegetation is mostly disturbed.

To study lichens three sites, each $100 \mathrm{~m}^{2}$ in area, at different elevations (high $<990 \mathrm{~m}$ ), (mid 950 $870 \mathrm{~m}$ ) and (low $700-650 \mathrm{~m}$ ) were selected. Three trees Alstonia macrophylla, Albizzia lebbek, Macaranga tomentosa were selected to study corticolous lichens. Alstonia macrophylla was present in all sites while Albizzia lebbek was present in sites one and three. Macaranga tomentosa was present in site two only. Rocks vere used for sexicolous species. Total percentage lichen cover and the total number of different lichens were recorded by placing $250 \mathrm{~cm}^{2}$ quadrate randomly on trunks of trees (six trees and four quadrate /tree and three rocks per site). Light intensity, bark $\mathrm{pH}$ of trees and relative humidity were measured in all sites.

In site one, Parmotrema reticulatum had the highest percentage cover (29.3\%) while Buellia sp. 1 had the second highest coverage value (10.6\%) on $A$ macrophylla. On rocks, Diploschistes sp. had the highest coverage value while Aspicilia sp. anc Toninia sp. was recorded with fairly high coverage. On the trunks of $A$. lebbek, several species of Usnea were recorded in this site.

In site two, on $A$. macrophylla, Pertusaria sp. I was recorded with highest coverage (14.3\%) while Pyrenula sp. and Letrouitia sp. 1 had coverage values of 11.46 and 6.67 respectively. On rocks a species of Leotogium, Dirinaria aegialita and Pertusaria species were recorded with higher coverage values. Pertusaria sp. was recorded from all three substrates in this site.

In site three, on $A$. lebbek, Parmotrema reticulatum gave the highest coverage value while Drynaria aegilita had the second higher value. Helerodermia sp. 3 had the highest percentage cover on rocks.

Twenty-five different lichens were identified in site one while site two and three had lesser number of lichens. Total number of lichens on $A$. lebbek and $A$. macrophylla differ significantly at lower elevation but not in other two sites at higher elevation.

Statistical analyses of coverage values of lichens on diferent substrate within a site did not show a significant difference. Coverage values of lichens cn same trees, among sites also did not show a significant difference except on $A$. macrophylla. Lichen coverage on rocks was not significantly different between sites one and three.

Light intensity and relative humidity may be having a grater influence on the distribution of lichens. Effect of bark $\mathrm{pH}$ on lichen coverage was dificult to interpret.

Forty-five lichens species, which belong to nine genera, were identified in this locality. Eight lichen species were found to be new records in Sri Lanka.

Presence of indicator species such as Letrouitia, Liploschistes, Leptogium, Heterdermia and Pyrenula with good coverage on Ambuluwawa Mourtain indicates absence of air pollution in this area. 